IZA DP No. 5549

Income Taxation of U.S. Households: Basic Facts

Nezih Guner

Remzi Kaygusuz

Gustavo Ventura

March 2011 


\title{
Income Taxation of U.S. Households: Basic Facts
}

\author{
Nezih Guner \\ ICREA-MOVE, Universitat Autonoma de Barcelona, \\ Barcelona GSE, CEPR and IZA \\ Remzi Kaygusuz \\ Sabanci University \\ Gustavo Ventura \\ University of lowa
}

Discussion Paper No. 5549
March 2011

IZA

P.O. Box 7240

53072 Bonn

Germany

Phone: +49-228-3894-0

Fax: +49-228-3894-180

E-mail: iza@iza.org

Any opinions expressed here are those of the author(s) and not those of IZA. Research published in this series may include views on policy, but the institute itself takes no institutional policy positions.

The Institute for the Study of Labor (IZA) in Bonn is a local and virtual international research center and a place of communication between science, politics and business. IZA is an independent nonprofit organization supported by Deutsche Post Foundation. The center is associated with the University of Bonn and offers a stimulating research environment through its international network, workshops and conferences, data service, project support, research visits and doctoral program. IZA engages in (i) original and internationally competitive research in all fields of labor economics, (ii) development of policy concepts, and (iii) dissemination of research results and concepts to the interested public.

IZA Discussion Papers often represent preliminary work and are circulated to encourage discussion. Citation of such a paper should account for its provisional character. A revised version may be available directly from the author. 
IZA Discussion Paper No. 5549

March 2011

\section{ABSTRACT}

\section{Income Taxation of U.S. Households: Basic Facts ${ }^{\star}$}

We use micro data from the U.S. Internal Revenue Service to document how households' tax liabilities vary with income, marital status and the number of dependents. We report facts on the distributions of average and marginal taxes, properties of the joint distributions of taxes paid and income, and discuss how taxes are affected by marital status and the number of children. The data reveals a large dispersion in tax rates and taxes paid. Ranking households according to the average tax rates they face, those at top $1 \%$ face taxes in excess of $27.5 \%$, while the median tax rate is about $8 \%$. About $14.5 \%$ of married and $31.8 \%$ of unmarried households do not pay any taxes. Given the progressivity in the system, tax liabilities are more unequally distributed than income. The top 5\% (1\%) of households account for $54 \%$ (34.8\%) of total tax liabilities, while top 5\% (1\%) of households have $34.8 \%(20.3 \%)$ of total income. We also provide parametric estimates of tax functions for use in applied work in macroeconomics and public finance.

JEL Classification: E62, H31, J12, J22

Keywords: taxation, tax progressivity, households

Corresponding author:

Nezih Guner

MOVE

Facultat d'Economia

Universitat Autònoma de Barcelona

Edifici B - Campus de Bellaterra

08193 Bellaterra, Cerdanyola del Vallès

Spain

E-mail: nezih.guner@movebarcelona.eu

\footnotetext{
* Guner acknowledges support from ERC Grant 263600. The usual disclaimer applies.
} 


\section{Introduction}

This paper has two goals. First, we aim to systematically describe how taxes paid by a cross-section of U.S. households vary according to their income, marital status and number of dependent children. Second, we provide estimates of effective tax functions that capture the observed heterogeneity in the data that can be readily used in applied work.

Both goals above are motivated by the large and growing body of literature that utilizes dynamic macroeconomic models with heterogeneous households; see Heathcote, Storesletten and Violante (2009) for a recent survey. This literature has studied how existing models can account for properties of actual earnings, income and wealth distributions, and has used such models to address a host of policy questions. ${ }^{1}$ As an input in this process, a large body of work, old and new and from related fields, documented the empirical properties of such distributions. However, the distribution of taxes effectively paid by households and the marginal tax rates that they face have received much less attention. This paper fills this void, by systematically documenting basic properties of the structure of income taxation for a cross section of U.S. households.

The model economies studied in the above mentioned literature require, in accordance with data, a mapping of household's income to taxes paid conceivably depending on the household's marital status and the presence of children. This naturally matters when asking how well models with heterogeneous households match distributional properties of data, as well as for the fruitful use of these frameworks to address policy questions. A ready-to-use, systematic representation of this mapping is not currently available for different types of households, and we offer it here. Therefore, we provide different parametric estimates of effective taxes as a function of household's income for different types of households; all, married, unmarried, with and without dependent children.

We use a large cross-sectional data set from U.S. Internal Revenue Service (IRS) for our purposes ('Public Use Tax File'), that is representative of the entire set of U.S. taxpayers. For a notion of effective average tax rates, we find a substantial degree of heterogeneity implied by the U.S. income tax system and the underlying distribution of income. As we document, average rates increase non trivially with income, and this is reflected in the distribution of average tax rates paid. For instance, if we rank the married households by average tax rates

\footnotetext{
${ }^{1}$ There is a large literature tax uses dynamic macroecomic models with heterogenous agents to study tax reforms. See Ventura (1999), Altig, Auerbach, Kotlikoff, Smetters and Walliser (2001), Castañeda, Díaz-Jiménez and Ríos-Rull (2003), Díaz-Jiménez and Pijoan-Mas (2005), Nishiyama and Smetters (2005), Conesa and Krueger (2006), Erosa and Koreshkova (2007), and Conesa, Kitao and Krueger (2009), among others. Guvenen, Kuruscu and Ozkan (2009) study the effect of taxes on human capital accumulation and inequality.
} 
that they face, average taxes at top $1 \%$ are in excess of $27.5 \%$, while the median tax rate is about $8 \%$. These facts, in conjunction with the substantial income dispersion that we document in this data, implies that households at the top of the income distribution account for the bulk of taxes paid; the top $5 \%$ accounts for nearly $54 \%$ of all taxes paid, whereas the top $1 \%$ accounts for about $34.8 \%$.

Using this data, we estimate two functional forms for effective tax rates. In each case, we report estimates for all households, as well as for married and unmarried households with different numbers of dependent children. We first estimate a two-parameter specification, which we refer to as the $\log$ specification. Our second set of estimates is for the same functional form used in Gouveia and Strauss (1994), who provided estimates of tax functions for all taxpayers using the U.S. tax structure prevailing in $1989 .^{2}$ We find that both specifications provide tax schedules for average rates that are quite similar. We also find that the implied schedules of marginal tax rates, computed from the effective tax functions, differ substantially from statutory rates. In addition, the schedules become essentially flat after relatively low levels of income under the Gouveia and Strauss specification. The log specification, in contrast, generates marginal rates that increase with income as in the tax law.

The paper is organized as follows. Section 2 presents the basic data that we use in our calculations afterwards. Section 3 describes how effective average tax rates (and reported marginal tax rates) by households vary in cross section according to income, depending on marital status and the number of dependent children. Section 4 reports facts on the distribution of tax rates and taxes paid. Section 6 offers the parametric estimates for tax functions. Section 7 concludes.

\section{Data}

We use data from the Internal Revenue Service 2000 Public Use Tax File. With 145,663 records, it is a representative subsample of the universe of U.S. taxpayers who filed taxes in the year 2000. Since this data effectively contains no restrictions on income, either at the bottom or at the top, it allows for a comprehensive representation of income and tax

\footnotetext{
${ }^{2}$ Several papers estimated effective tax rates for the use in representative-agent models. See, for instance, Joines (1981), Seater (1982), Barro and Sahasakul (1983) for papers that used IRS data, and Mendoza, Razin and Tesar (1994) who estimated effective taxes for a large set of countries using national accounts and revenue statistics. Differently from these papers, Gouveia and Strauss (1994) used IRS data to estimate tax functions-average tax rates as a function of household income.
} 
liabilities. $^{3}$

The notion of income that we use is standard in cross-sectional studies and encompasses all income flows accruing to households; labor income, asset income from different sources and transfers. It corresponds closely to the notion employed by Gouveia and Strauss (1994). We define income to include

- Salaries and wages;

- Interest income (taxable and not taxable);

- Dividends;

- Business or professional income;

- Total pensions and annuities received plus taxable IRA distributions;

- Unemployment compensation;

- Social Security benefits;

- State income tax refunds and alimony received.

It is worth emphasizing that the notion of income that we use is different from the legal notions Adjusted Gross Income and Taxable Income. Adjusted Gross Income was computed in 2000 by subtracting from all reported income flows IRA and other tax deferred contributions for retirement plans (e.g. 401-k), moving expenses, student loans interest, alimony paid, contributions to medical income savings accounts, among other items. Taxable Income is obtained by subtracted personal exemptions and deductions from Adjusted Gross Income. ${ }^{4}$

Our notion of Federal taxes is comprehensive as well. It corresponds to total income taxes owed after Credits (including the Earned-Income Tax credit). ${ }^{5}$ From this notion of tax liabilities, we calculate for our purposes effective average tax rates. Reported marginal tax rates correspond to the statutory marginal rates for each household given their taxable income in the data.

\footnotetext{
${ }^{3}$ For details on variable definitions, weights used and other technical details, see the Individual Tax File Sample Description booklet that accompanies the data.

${ }^{4}$ In terms of deductions, households can choose between a lump-sum standard deduction or multiple itemized deductions, the most common of which corresponds to mortgage interest paid.

${ }^{5}$ More specifically, we use the variable TOTAL INCOME TAX (E06500) in the 2000 Public Use Tax File.
} 
Sample Restrictions Households are included in the sample if (i) their income is higher than $\$ 5,000$, which is roughly equivalent to half of the hypothetical income of a worker, who works at the minimum wage ( $\$ 5.15$ in the year 2000); (ii) their average tax rate is less than $40 \%$. The second restriction eliminates those with reported taxes higher than the top marginal tax rate, $39.5 \%$. The resulting average level of income is US\$ 58,375. The corresponding average level of household income from Current Population Survey (CPS) data is only slightly lower: US $\$ 57,121$.

\subsection{Statutory Taxes in 2000}

Before presenting and discussing results on taxes paid by income, household structure and number of children, it is worth reporting the structure of statutory income taxes in 2000 . Table 1 summarizes this information for three relevant categories: married filing jointly, single and head of household. Tax brackets are presented as defined in the law, according to the legal notion of Taxable Income.

As the table shows, marginal tax rates range from $15 \%$ to $39.5 \%$. The standard deduction for married people is not twice the standard deduction for singles. A similar remark applies to the width of the tax brackets. Very importantly, there is a wide range of income for which marginal tax rates are unchanged; for instance, from $\$ 43,850$ to $\$ 161,450$ for married households, marginal rates change by only three percentage points (from 28 to 31 percent). Afterwards, marginal rates increase non-trivially for high- income earners; to 36 and 39.6 percent, respectively. Altogether, these features contribute to generate the substantial differences in average tax rates across income levels displayed in Table 1.

\subsection{Descriptive Income Statistics}

For a better understanding on the facts about tax liabilities in cross section, it is of interest to report on the properties of the distribution of income in the tax data. This is of interest, since as the data is representative of the entire universe of U.S. taxpayers, there are no top-coding restrictions as in other commonly used data sets (e.g. PSID, CPS).

Table 2 summarizes the properties of the income distribution and highlights the substantial degree of concentration of income at the top. The richest $20 \%$ of households earns about $59.3 \%$ of total income, whereas the top $10 \%, 5 \%$ and $1 \%$ earn about $45.0 \%, 34.8 \%$ and $20.3 \%$, respectively. From the Table also transpires the importance of the very rich: the top $0.5 \%$ earn about $16.2 \%$ of income.

Table 2 also shows the varying composition of income as income increases. The last 
columns in the upper panel display the fraction of income corresponding to capital income at different quintiles for two concepts of capital income. The first concept of capital income, includes all interest income, dividends, $1 / 3$ of business income, capital gains, rental + royalties income and $1 / 3$ of farm income. ${ }^{6}$ The more comprehensive second one, adds to the previous one all pension and annuity payments. In both cases, and as expected, capital income as a share of total income rises rapidly as income goes up. Note that at the very top, almost half of income accrues from capital income under the first definition (about 48.2\%), whereas under the second notion about $59.5 \%$ of income derives from capital income. This is obviously relevant for economic purposes; high income households face much higher marginal tax rates (see below) and capital income is concentrated there.

It is important to relate these summary distributional statistics to standard summary measures of income inequality. For instance, CPS data indicates that each quantile earned in 2000 about $3.6,8.9,14.8,23.0$ and 49.8 percent of income respectively, whereas the top $5 \%$ earned about 22.1 percent with a Gini coefficient of about $46.2 .^{7}$ The tax data shows that each quintile earned about 3.4, 6.9, 11.6, 18.8 and 59.3 percent, respectively, whereas the top $5 \%$ earned about $34.8 \%$ with a Gini coefficient of about 0.554 . Clearly, and as also emphasized by others (e.g. Piketty and Saez 2003), the degree of income concentration from tax data is substantially higher than the degree of income concentration emerging from standard data sets.

\section{Income Taxes in Cross Section}

In this section we report basic facts on how average and marginal tax rates vary according to our broad notion of income, marital status and the number of children. We proceed by dividing households in cells determined by multiples of mean income, where each cell captures all households whose income is at half the distance between the next upper and lower cell. The lowest multiple covers all income below it, whereas the highest income covers all income above it.

For each cell, we calculate the effective average rate, defined as the average ratio of taxes paid to household's income in the cell. The marginal rate that we report corresponds to the one faced by households in their tax filing, averaged across all households in the cell. Thus, the marginal tax rate reported corresponds to mean statutory marginal rates. We also report the standard deviation for average and marginal tax rates in each cell. Finally, we also report

\footnotetext{
${ }^{6}$ We allocate $1 / 3$ of business and farm income according to standard estimates of the share of capital income in total income.

${ }^{7}$ See http://www . census .gov/hhes/www/income/data/historical/household/index.html
} 
the ratio of marginal to average taxes for each cell, as a measure of the progressivity of the tax system.

\subsection{Married and Unmarried Households}

Tables 3 and 4 show the findings for married and unmarried households. Married households correspond to those filing as married filing jointly, whereas unmarried households encompass all those filing as single and as head of household. We explicitly include head of households in our unmarried group, as this category is designed for households headed with unmarried individuals with dependents.

A central finding from Tables 3 and 4 is that effective average rates increase substantially as income increases. Increasing household income from the mean income level to five times mean income (i.e. from $\$ 58,375$ to about $\$ 291,875$ ), increases the mean, effectively-paid average tax rate, from about $8.8 \%$ to $20.5 \%$ for married households, and from $14.2 \%$ to $20.2 \%$ for unmarried households. In terms marginal rates, the increase goes from $18.9 \%$ to $34.0 \%$ for married households, and from $26.2 \%$ to $32.5 \%$ for unmarried ones. For ten times mean income, average (marginal) rates are $24.3 \%$ (36.9\%) for married households and $23.1 \%$ $(35.0 \%)$ for unmarried ones. Hence, from these findings it is clear that there is a non-trivial degree of tax progressivity built in the tax system. This is also illustrated in ratio of marginal to average tax rates. In Tables 3 and 4 (as well as in similar tables that follow), this ratio is substantially higher than 1 at low incomes levels and declines rather monotonically to numbers around 1.3-1.8 at higher income levels. ${ }^{8}$

From Tables 3 and 4 also transpire that there are substantial differences in average rates between married and unmarried households. At low levels of income, effective rates are substantially higher for unmarried households, while these rates subsequently converge as income increases. This is due to a host of factors; children, differences in standard deductions as well as differences in the width of tax brackets. These factors are arguably more important in reducing average rates at lower levels of income. For instance, children are concentrated in married households and they lead to higher personal exemptions and tax credits, thereby reducing average rates for these households.

We now try to illustrate the effects of the differential tax treatment of married and single households in the United States. To isolate these effects, we use data that is not affected by the presence of children (Tables 5 and 8). Consider for instance a married household with an income level equal to twice the mean income level. If both wife and husband have the same income, their tax liabilities are higher when married; they would pay as a married

\footnotetext{
${ }^{8}$ Prescott (2004) uses a ratio of 1.6 for the U.S. economy.
} 
household an effective average rate of about $15.7 \%$ whereas as two single individuals, they would pay about $15.3 \%$ each. At another extreme, if only one of them earns an income of twice mean income, the average rate would be about $17.1 \%$ if each filed as single, whereas it would be $15.7 \%$ if they filed as a married couple. Other combinations can be constructed from these tables, reflecting the fact that two partners of similar incomes face a tax penalty if they marry, whereas those with sufficiently different incomes face a tax bonus or subsidy. ${ }^{9}$

Overall, the discussion above is driven by the fact that in the United States, the unit subject to taxation is the household, not the individual. The economic implications of this fact go beyond relative payments when married or single. Consider again a married household with no children with an income level of twice the mean income level. Table 5 indicates that this household faces a marginal tax of about $27.7 \%$. If all income is earned by one household member, the marginal tax on the first dollar of income earned by the other household member is also taxed at the same rate, $27.7 \%$. This naturally creates large disincentives for labor supply of secondary earners. In contrast, if her/his income were treated as an individual income, the marginal tax rate would be substantially lower. ${ }^{10}$ If children are present, the same logic applies.

\subsection{The Role of Children}

Tables 5, 6 and 7 illustrate the quantitative importance of children in affecting average effective rates for married households, whereas tables 8,9 and 10 provide the equivalent information for unmarried households. As we mentioned earlier, for unmarried households, we use information from the single filing category for those without children, whereas for those with children we use information from the head of household category.

For married households, children reduce effective rates albeit the effect is not substantial. Households with income about twice mean income, face an effective average rate of about $15.7 \%$ when no children are present, a rate of about $14.1 \%$ when two children are present, and a rate of $12.7 \%$ when more than two children are present. Therefore, for these households, at extremes, the reduction in effective rates driven by the presence of children is of about three percentage points. At high levels of income, the corresponding reductions in average rates is smaller. Meanwhile, for poorer married households the reduction is naturally

\footnotetext{
${ }^{9}$ See McCaffery (1997) for a detailed account of the US tax system's treatment of married and single households. On the optimal taxation of couples, see Boskin and Sheshinski (1983), Apps and Rees (2010), Alessina, Ichino, and Karabarbounis (2010) and Kleven, Kreiner, and Saez (2009).

${ }^{10}$ In Guner, Kaygusuz and Ventura (2010), we show that these features of the U.S. tax law have large effects on labor supply of married females. Kaygusuz (2010) studies how much changes in taxes contributed to the growth of married female labor supply in the US since 1970s.
} 
higher; nearly five percentage points at mean income levels. This is not at all surprising: children disproportionately affect tax liabilities of poorer households via lump-sum personal exemptions and tax credits.

\section{The Distribution of Tax Rates and Taxes Paid}

We report in this section facts on the distribution of tax rates and the taxes paid. Table 11 describes the basic features of the distribution of average tax rates across households. This information is also presented graphically in Figure 1. As the table illustrates, a substantial fraction of households has no tax liabilities: this occurs for about $14.5 \%$ of the married group and for about $31.8 \%$ of the unmarried one. Median and mean effective tax rates are on the low side for both groups, with a median rate for married households of about $8.0 \%$ and a mean rate for married households of about $8.8 \%$. For unmarried households, the median rate is of about $5.6 \%$ whereas the mean rate equals $6.4 \%$.

The bottom panel of Table 11 shows the tax rates defining the top percentiles. Households at the top of the distribution face significantly higher average rates than those around the middle: the ratio of tax rates defining the top $5 \%$ to the median is in excess of a factor of 2 for married households, and of a factor of 3 for unmarried households.

A related question is: How tax liabilities are distributed? Table 12 answers this question, by calculating the share of total taxes paid by different percentiles of the income distribution. The top $20 \%$ of households earns about $59.3 \%$ of total income and pays more than three quarters of total taxes. Similarly, the top $1 \%$ earns about $20.3 \%$ of total income, yet it accounts for nearly $35 \%$ of total tax collections.

Overall, a clear picture emerges. First, and in connection with the results shown earlier in section 3.1 on the measured progressivity on the tax schedule, effective tax rates on most households are relatively low (below 10\%) and differ non trivially from those at the top. Thus, there is substantial heterogeneity in the tax burden as measured by effective average tax rates. Secondly, the provisions in the law, in conjunction with the observed dispersion in income in the data, lead to the finding that the overwhelming bulk of tax revenues are concentrated in upper income households.

\section{After-Tax Income Distribution}

How much before and after-tax income distributions differ? The IRS micro data is ideal to answer this question. Table 13 shows income distribution statistics before and after taxes. 
Despite the vast heterogeneity we documented earlier in terms of income and tax payments, the results show a rather limited degree of redistribution stemming from the U.S. tax system. From Table 13 emerges a clear picture: the shares accruing to each percentile on the after-tax income distribution are similar to those from the before-tax income distribution. The same tends to be the case for the summary measures of inequality. For instance, the Gini coefficient declines slightly from the before-tax to the after-tax income distribution (0.554 to 0.522$)$.

\section{Parametric Estimates}

In this section, we provide estimates of tax functions for applied use. Specifically, we posit parametric functional forms for effective average tax rates, and estimate the relevant parameters for all households, married and unmarried households, distinguishing by the number of dependent children. As we explain below, the parameters that we estimate can be easily used in applied work. ${ }^{11}$

We estimate two specifications for average tax rates. In the first case, we posit that

$$
t(\tilde{y})=\alpha+\beta \log (\tilde{y})
$$

where $t$ is the average tax rate, and the variable $\tilde{y}$ stands for multiples of mean household income in the data. That is, a value of $\tilde{y}$ equal to 2.0 implies an average tax rate corresponding to an actual level of income that is twice the magnitude of mean household income in the data. We refer to this as the $\log$ specification.

Notice that for this specification, marginal tax rates, $m$, are given by

$$
m(\tilde{y})=\alpha+\beta \log (\tilde{y})+\beta=t(\tilde{y})+\beta .
$$

That is, marginal tax rates differ from average tax rates by the constant factor $\beta$. In macroeconomic terms, this specification is consistent with balanced growth: if all incomes increase by a given factor, average and marginal tax rates are unchanged, and total taxes paid increase by the same factor.

In our second specification, we estimate the same functional form used by Gouveia and Strauss (1994)

$$
t(y)=b\left[1-\left(s y^{p}+1\right)^{-1 / p}\right] .
$$

\footnotetext{
${ }^{11}$ Guvenen, Kaygusuz and Ozkan (2009), Huggett and Parra (2010), and Heatchote, Storesletten and Violante (2011) also estimate effective tax functions using different specifications and data sets.
} 
In this case, the variable $y$ stands for the level of household income in the data set. We refer to this as the $G S$ specification. The corresponding marginal tax function is

$$
m(y)=b\left[1-\left(s y^{p}+1\right)^{-1 / p-1}\right]
$$

Tables 14, 15, 16 and 17 show the parameter estimates for married and unmarried households, with and without children present in the household.

For illustration purposes, Figure 2 plots the resulting average tax rates under both specifications for the case of all married households. The figure shows that the resulting shape of average tax rates are quite similar under both cases, and converge to essentially the same values for high levels of income. Note also that the log specification yields, not surprisingly, negative values for sufficiently low levels of income. The log specification implies that a married household around mean income (twice mean income) has an average rate of about $9.2 \%(13.7 \%)$. The corresponding values under the $G S$ specification are $8.2 \%$ (14.4\%).

The reported estimates are quite easy to interpret for the $\log$ specification. Note that when $\tilde{y}$ equal 1.0, the household income corresponds to mean income, and the average tax rate equals $\alpha$, and the marginal rate equals $\alpha+\beta$. The role of children and marital status are straightforward; average and marginal rates are lower for married households, and tend to decrease with the presence of children in the household.

Marginal Tax Rates Figure 3 plots the marginal tax rates for the case of married households implied by our parameter estimates. For the log case, since the marginal rate differs from the average rate by the constant factor $\beta$, marginal rates increase with income and become closer to average rates as income goes up.

It is important to emphasize that the marginal rates calculated from equations (1) and (2) are derived from our previous calculation of average effective rates. As such, they differ from statutory marginal rates and reflect some (but not all) of the tax distortions on economic activity built into the system. Effective rates reflect the inframarginal exemptions, deductions, etc., that reduce average rates. Yet, for many economic decisions the relevant marginal rates are those from the actual tax schedule (statutory rates), as they are the operative ones for decisions on the margin; e.g. to work overtime or not, labor force participation decisions of secondary earners, buying or selling extra units of assets, etc.

How much do effective marginal rates differ from statutory rates? This is shown in table 18. For illustration purposes, consider the case of all married households. At mean levels of income, statutory and marginal tax rates are relatively similar; the mean statutory marginal rate amounts to about $18.9 \%$, whereas the effective marginal rates are $15.6 \%$ under the log 
specification and $16.9 \%$ under the GS specification. However, the gap between effective and statutory rates grows strongly with income. At a five-times mean income level, the statutory rate averages $34 \%$, whereas the effective marginal rates amount to $25.9 \%$ under the $\log$ specification and $24.5 \%$ under the $G S$ specification. As table 18 illustrates, this gap is even higher at higher levels of income. It is worth noting that the marginal rates emerging from the $G S$ specification become essentially constant after relatively low levels of income (about twice mean income), which potentially limits their use in applied work. In contrast, the log specification, by generating increasing marginal rates as a function of income, better reflects the distortions on economic activity associated to rising statutory marginal tax rates.

Comparisons with Previous Estimates It is of interest to compare the estimated tax functions with the existing ones from Gouveia and Strauss (1994), who provided estimates for effective rates using data from 1980 and 1989 for all households. This comparison is displayed in Figure 4, where the corresponding average rates are plotted for these three years. ${ }^{12}$

The figure indicates that there are only minor differences in the resulting average tax functions between 1989 and 2000. Differences occur only at higher income levels and are in the ballpark of one percentage point. The results largely suggest that changes in taxes that took place in 1991 and 1994 did not affect effective average rates significantly. In contrast, as the figure demonstrates, the changes in the tax structure that took place in the 1980's, affected the shape of average rates significantly. For higher income households, the differences are quite substantial; for instance, at five time mean income levels, the differences between 2000 and 1980 is in excess of eleven percentage points.

\section{Conclusion}

We presented basic facts on the effective taxation of U.S. households in cross-section, distinguishing them by their marital status and the number of dependent children. We also provide parametric estimates of effective tax functions for two specifications that can be readily used in applied work.

\footnotetext{
${ }^{12}$ For comparison purposes, nominal income has been adjusted, and the estimated parameter $s$ has been adjusted for 1980 in order to make the comparison possible.
} 


\section{References}

[1] Alesina, A., Ichino, A. and L. Karabarbounis, "Gender Based Taxation and the Division of Family Chores," mimeo, 2010, forthcoming American Economic Journal: Economic Policy.

[2] Altig, D., Auerbach, A., Kotlikoff, L., Smetters, K., and J. Walliser, "Simulating Fundamental Tax Reform in the United States," American Economic Review, vol. 91, no. 3 (June 2001), 574-595.

[3] Apps, P. and R. Rees, "Taxation of Couples," in A Cigno, P Pestieau and R Rees (eds), Taxation and the Family, MIT Press (forthcoming), 2010.

[4] Barro, R. T. and C. Sahasakul. "Measuring the Average Marginal Tax Rate from Individual Income Tax," Journal of Business, vol. 56(4), 1983 419-452.

[5] Boskin, M. J. and E. Sheshinski, "Optimal tax treatment of the family: Married couples," Journal of Public Economics, vol. 20, no. 3 (April 1983), 281-297.

[6] Caucutt, E., Imrohoroglu, S. and K. B. Kumar, "Growth and Welfare Analysis of Tax Progressivity in a Heterogeneous-Agent Model," Review of Economic Dynamics, vol. 6 (3), 2003, 546- 577.

[7] Castañeda, A, Díaz-Giménez, J. and J. V. Ríos-Rull, "Accountig for the US Earnings and Wealth Inequality", Journal of Political Economy, vol. 111, no. 4 (August 2003), 818-857.

[8] Conesa, J. C. and D. Krueger, "On the Optimal Progressivity of the Income Tax Code," Journal of Monetary Economics, vol. 53., no. 7, (October 2006), 1425-1450.

[9] Conesa, J. C., Kitao, S. and D. Krueger "Taxing Capital? Not a Bad Idea after All!," American Economic Review, vol. 99, no.1 (March 2009), 25-48.

[10] Diaz-Gimenez, J. and J. Pijoan-Mas, "Flat Tax Reforms in the U.S.: A Boon for the Income Poor," mimeo, 2005.

[11] Erosa, A. and T. Koreshkova, "Progressive Taxation in a Dynastic Model of Human Capital," Journal of Monetary Economics, vol. 54, no. 3 (April 2007), pages 667-685.

[12] Gouvieia, M. and R. Strauss. "Effective Federal Individual Income Tax Functions: An Exploratory Analysis," National Tax Journal, vol. 47(2), 1994, 317-39. 
[13] Guner, N., Kaygusuz, R. and G. Ventura. Taxation and Household Labor Supply, mimeo, 2010.

[14] Guvenen, F., Kuruscu, B. and S. Ozkan, "Taxation of Human Capital and Wage Inequality: A Cross-Country Analysis," mimeo 2009.

[15] Heathcote, J., Storesletten, J. and G. L. Violante. "Quantitative Macroeconomics with Heterogeneous Households," Annual Review of Economics, vol. 1, 2009, 319-354.

[16] Heathcote, J., Storesletten, J. and G. L. Violante. "Redistributive Taxation in a PartialInsurance Economy," mimeo, 2011.

[17] Huggett, M. and J. C. Parra. "How Well Does the US Social Insurance System Provide Social Insurance?" Journal of Political Economy, 118 (1), 2010, 76-112.

[18] Joines, D. H. "Estimates of Effective Marginal Tax Rates on Factor Incomes," Journal of Business, 54(2), 1981, 191-226.

[19] Kaygusuz, R. "Taxes and Female Labor Supply," Review of Economic Dynamics, vol. 13, no.4 (October 2010), 725-741.

[20] Kleven, H., Kreiner, C.T. and E. Saez, 2009, "The Optimal Taxation of Couples," Econometrica, 77, 537-560.

[21] McCaffery, E. J. Taxing Women. The University of Chicago Press: Chicago, IL. 1997.

[22] Mendoza, E. G., A. Razin, L. L. Tesar, "Effective Tax Rates in Macroeconomics: CrossCountry Estimates of Tax Rates on Factor Incomes and Consumption," Journal of Monetary Economics, 34 (3), 1994, 297-323.

[23] Nishiyama, S. and K. Smetters, "Consumption Taxes and Economic Efficiency with Idiosyncratic Wage Shocks," Journal of Political Economy, vol.113, no.5 (October 2005), 1088-1115.

[24] Piketty, T. and E. Saez. "Income Inequality in the United States, 1913-1998", Quarterly Journal of Economics, 118(1), 2003, 1-39.

[25] Prescott, E. "Why Do Americans Work So Much More Than Europeans?," Federal Reserve Bank of Minneapolis Quarterly Review, 2004, 2-13.

[26] Seater, E. M. "Marginal Federal Personal and Corporate Income Tax Rates in the U.S., 1909-1975," Journal of Monetary Economics, 10(3), 1982, 121-135. 
[27] Ventura, G., "Flat Tax Reform: A Quantitative Exploration," Journal of Economic Dynamics $\& 3$ Control, vol. 23, no. 9-10, (September 1999), 1425-1458. 
Table 1: 2000 Income Tax Schedule

\begin{tabular}{|c|c|c|c|}
\hline Marginal Tax Rate & $\begin{array}{c}\text { Married Filing Jointly } \\
\text { Tax Brackets } \\
\text { (Taxable Income) }\end{array}$ & $\begin{array}{c}\frac{\text { Single }}{\text { Tax Brackets }} \\
\text { (Taxable Income) }\end{array}$ & $\begin{array}{c}\frac{\text { Head of Household }}{\text { Tax Brackets }} \\
\text { (Taxable Income) }\end{array}$ \\
\hline $15.0 \%$ & $0-43,850$ & $0-26,250$ & $0-35,150$ \\
$28.0 \%$ & $43,850-105,950$ & $26,250-63,550$ & $35,150-90,800$ \\
$31.0 \%$ & $105,950-161,450$ & $63,550-132,600$ & $90,800-147,050$ \\
$36.0 \%$ & $161,450-288,350$ & $132,600-288,350$ & $147,050-288,350$ \\
over 288,350 & over 288,350 \\
$39.6 \%$ & over 288,350 & & \\
\hline Standard & $\$ 7,350$ & $\$ 4,400$ & $\$ 6,450$ \\
Deduction & 2,800 & 2,800 & 2,800 \\
\hline Personal & & & \\
Exemption & & & \\
\hline
\end{tabular}


Table 2: Income Distribution Statistics

\begin{tabular}{|l|c|c|c|}
\hline Percentile & $\begin{array}{c}\text { Share of } \\
\text { Total Income }\end{array}$ & $\begin{array}{c}\text { Contribution of } \\
\text { Capital Income (I) }\end{array}$ & $\begin{array}{c}\text { Contribution of } \\
\text { Capital Income (II) }\end{array}$ \\
\hline Bottom 20\% & $3.4 \%$ & $9.5 \%$ & $15.5 \%$ \\
$20-40 \%$ & $6.9 \%$ & $7.0 \%$ & $13.8 \%$ \\
$40-60 \%$ & $11.6 \%$ & $6.7 \%$ & $13.3 \%$ \\
$60-80 \%$ & $18.8 \%$ & $9.1 \%$ & $17.0 \%$ \\
$80-90 \%$ & $14.3 \%$ & $10.4 \%$ & $18.1 \%$ \\
$90-95 \%$ & $10.2 \%$ & $16.0 \%$ & $23.7 \%$ \\
$95-99 \%$ & $14.5 \%$ & $25.3 \%$ & $35.6 \%$ \\
$99-99.5 \%$ & $4.0 \%$ & $36.5 \%$ & $51.3 \%$ \\
$99.5-100 \%$ & $16.2 \%$ & $48.2 \%$ & \\
& & & \\
\hline Other Statistics & & & 0.554 \\
Income Share of & $59.3 \%$ & Gini Coefficient & \\
Top 20\% & $45.0 \%$ & Var-log Income & 0.85 \\
Top 10\% & $34.8 \%$ & & \\
Top 5\% & $20.3 \%$ & & \\
Top 1\% & & \\
\hline
\end{tabular}

Table 3: Descriptive Tax Statistics: Married Households

\begin{tabular}{|l|c|c|c|c|c|}
\hline $\begin{array}{l}\text { Multiples of } \\
\text { Mean Income }\end{array}$ & $\begin{array}{c}\text { Avg. Tax Rate } \\
\text { (Mean) }\end{array}$ & $\begin{array}{c}\text { Marg. Tax Rate } \\
\text { (Mean) }\end{array}$ & Marg./Avg. & $\begin{array}{c}\text { Avg. Tax Rate } \\
\text { (St. Dev.) }\end{array}$ & $\begin{array}{c}\text { Marg. Tax Rate } \\
\text { (St. Dev.) }\end{array}$ \\
\hline 0.10 & 0.000 & 0.001 & - & 0.004 & 0.012 \\
0.25 & 0.011 & 0.073 & 6.64 & 0.020 & 0.075 \\
0.50 & 0.035 & 0.132 & 3.77 & 0.033 & 0.049 \\
0.75 & 0.064 & 0.147 & 2.45 & 0.033 & 0.021 \\
1.0 & 0.088 & 0.189 & 2.15 & 0.030 & 0.061 \\
1.5 & 0.119 & 0.264 & 2.22 & 0.036 & 0.044 \\
2.0 & 0.149 & 0.277 & 1.86 & 0.037 & 0.029 \\
3.0 & 0.168 & 0.297 & 1.77 & 0.046 & 0.036 \\
4.0 & 0.187 & 0.326 & 1.74 & 0.059 & 0.049 \\
5.0 & 0.205 & 0.340 & 1.66 & 0.070 & 0.052 \\
7.0 & 0.213 & 0.355 & 1.67 & 0.087 & 0.065 \\
10.0 & 0.243 & 0.369 & 1.52 & 0.097 & 0.059 \\
\hline
\end{tabular}


Table 4: Descriptive Tax Statistics: Unmarried Households

\begin{tabular}{|l|c|c|c|c|c|}
\hline $\begin{array}{l}\text { Multiples of } \\
\text { Mean Income }\end{array}$ & $\begin{array}{c}\text { Avg. Tax Rate } \\
\text { (Mean) }\end{array}$ & $\begin{array}{c}\text { Marg. Tax Rate } \\
\text { (Mean) }\end{array}$ & Marg./Avg. & $\begin{array}{c}\text { Avg. Tax Rate } \\
\text { (St. Deviation) }\end{array}$ & $\begin{array}{c}\text { Marg. Tax Rate } \\
\text { (St. Deviation) }\end{array}$ \\
\hline 0.10 & 0.022 & 0.078 & 3.55 & 0.034 & 0.075 \\
0.25 & 0.046 & 0.128 & 2.78 & 0.041 & 0.052 \\
0.50 & 0.080 & 0.156 & 1.95 & 0.040 & 0.037 \\
0.75 & 0.114 & 0.228 & 2.00 & 0.039 & 0.066 \\
1.0 & 0.142 & 0.262 & 1.85 & 0.045 & 0.048 \\
1.5 & 0.162 & 0.280 & 1.73 & 0.054 & 0.048 \\
2.0 & 0.170 & 0.287 & 1.69 & 0.063 & 0.049 \\
3.0 & 0.179 & 0.307 & 1.72 & 0.074 & 0.055 \\
4.0 & 0.202 & 0.326 & 1.61 & 0.076 & 0.061 \\
5.0 & 0.202 & 0.325 & 1.61 & 0.087 & 0.071 \\
7.0 & 0.194 & 0.339 & 1.75 & 0.100 & 0.071 \\
10.0 & 0.231 & 0.350 & 1.52 & 0.105 & 0.078 \\
\hline
\end{tabular}

Table 5: Descriptive Tax Statistics: Married Households, No Children

\begin{tabular}{|l|c|c|c|c|c|}
\hline $\begin{array}{l}\text { Multiples of } \\
\text { Mean Income }\end{array}$ & $\begin{array}{c}\text { Avg. Tax Rate } \\
\text { (Mean) }\end{array}$ & $\begin{array}{c}\text { Marg. Tax Rate } \\
\text { (Mean) }\end{array}$ & Marg./Avg. & $\begin{array}{c}\text { Avg. Tax Rate } \\
\text { (St. Deviation) }\end{array}$ & $\begin{array}{c}\text { Marg. Tax Rate } \\
\text { (St. Deviation) }\end{array}$ \\
\hline 0.10 & 0.000 & 0.002 & - & 0.005 & 0.014 \\
0.25 & 0.019 & 0.095 & 5.00 & 0.023 & 0.072 \\
0.50 & 0.053 & 0.128 & 2.42 & 0.034 & 0.053 \\
0.75 & 0.074 & 0.146 & 1.97 & 0.034 & 0.025 \\
1.0 & 0.102 & 0.200 & 1.96 & 0.029 & 0.065 \\
1.5 & 0.135 & 0.266 & 1.97 & 0.034 & 0.043 \\
2.0 & 0.157 & 0.277 & 1.76 & 0.040 & 0.033 \\
3.0 & 0.170 & 0.293 & 1.72 & 0.051 & 0.045 \\
4.0 & 0.183 & 0.320 & 1.75 & 0.065 & 0.055 \\
5.0 & 0.197 & 0.330 & 1.68 & 0.075 & 0.061 \\
7.0 & 0.194 & 0.339 & 1.75 & 0.096 & 0.072 \\
10.0 & 0.222 & 0.359 & 1.62 & 0.105 & 0.065 \\
\hline
\end{tabular}


Table 6: Descriptive Tax Statistics: Married Households, Two Children

\begin{tabular}{|l|c|c|c|c|c|}
\hline $\begin{array}{l}\text { Multiples of } \\
\text { Mean Income }\end{array}$ & $\begin{array}{c}\text { Avg. Tax Rate } \\
\text { (Mean) }\end{array}$ & $\begin{array}{c}\text { Marg. Tax Rate } \\
\text { (Mean) }\end{array}$ & Marg./Avg. & $\begin{array}{c}\text { Avg. Tax Rate } \\
\text { (St. Deviation) }\end{array}$ & $\begin{array}{c}\text { Marg. Tax Rate } \\
\text { (St. Deviation) }\end{array}$ \\
\hline 0.10 & 0.001 & 0.001 & 1.0 & 0.005 & 0.012 \\
0.25 & 0.000 & 0.039 & - & 0.002 & 0.066 \\
0.50 & 0.015 & 0.140 & 9.33 & 0.019 & 0.037 \\
0.75 & 0.052 & 0.149 & 2.87 & 0.022 & 0.014 \\
1.0 & 0.073 & 0.174 & 2.38 & 0.022 & 0.052 \\
1.5 & 0.107 & 0.266 & 2.49 & 0.029 & 0.041 \\
2.0 & 0.141 & 0.277 & 1.96 & 0.032 & 0.028 \\
3.0 & 0.167 & 0.301 & 1.80 & 0.040 & 0.028 \\
4.0 & 0.187 & 0.329 & 1.76 & 0.058 & 0.046 \\
5.0 & 0.213 & 0.348 & 1.63 & 0.064 & 0.037 \\
7.0 & 0.233 & 0.373 & 1.60 & 0.071 & 0.045 \\
10.0 & 0.270 & 0.379 & 1.40 & 0.078 & 0.050 \\
\hline
\end{tabular}

Table 7: Descriptive Tax Statistics: Married Households, Two + Children

\begin{tabular}{|l|c|c|c|c|c|}
\hline $\begin{array}{l}\text { Multiples of } \\
\text { Mean Income }\end{array}$ & $\begin{array}{c}\text { Avg. Tax Rate } \\
\text { (Mean) }\end{array}$ & $\begin{array}{c}\text { Marg. Tax Rate } \\
\text { (Mean) }\end{array}$ & Marg./Avg. & $\begin{array}{c}\text { Avg. Tax Rate } \\
\text { (St. Deviation) }\end{array}$ & $\begin{array}{c}\text { Marg. Tax Rate } \\
\text { (St. Deviation) }\end{array}$ \\
\hline 0.10 & 0.000 & 0.000 & - & 0.000 & 0.000 \\
0.25 & 0.001 & 0.007 & 7.00 & 0.009 & 0.032 \\
0.50 & 0.003 & 0.117 & 39.00 & 0.009 & 0.062 \\
0.75 & 0.026 & 0.147 & 5.65 & 0.020 & 0.019 \\
1.0 & 0.055 & 0.161 & 2.93 & 0.022 & 0.041 \\
1.5 & 0.084 & 0.247 & 2.94 & 0.033 & 0.057 \\
2.0 & 0.127 & 0.276 & 2.17 & 0.034 & 0.025 \\
3.0 & 0.158 & 0.296 & 1.87 & 0.045 & 0.034 \\
4.0 & 0.186 & 0.332 & 1.78 & 0.049 & 0.038 \\
5.0 & 0.208 & 0.345 & 1.66 & 0.070 & 0.045 \\
7.0 & 0.233 & 0.372 & 1.60 & 0.076 & 0.046 \\
10.0 & 0.269 & 0.381 & 1.42 & 0.081 & 0.047 \\
\hline
\end{tabular}


Table 8: Descriptive Tax Statistics: Unmarried Households, No Children

\begin{tabular}{|l|c|c|c|c|c|}
\hline $\begin{array}{l}\text { Multiples of } \\
\text { Mean Income }\end{array}$ & $\begin{array}{c}\text { Avg. Tax Rate } \\
\text { (Mean) }\end{array}$ & $\begin{array}{c}\text { Marg. Tax Rate } \\
\text { (Mean) }\end{array}$ & Marg./Avg. & $\begin{array}{c}\text { Avg. Tax Rate } \\
\text { (St. Deviation) }\end{array}$ & $\begin{array}{c}\text { Marg. Tax Rate } \\
\text { (St. Deviation) }\end{array}$ \\
\hline 0.10 & 0.029 & 0.103 & 5.16 & 0.037 & 0.069 \\
0.25 & 0.069 & 0.142 & 2.06 & 0.032 & 0.033 \\
0.50 & 0.096 & 0.159 & 1.66 & 0.030 & 0.042 \\
0.75 & 0.125 & 0.251 & 2.01 & 0.036 & 0.057 \\
1.0 & 0.153 & 0.268 & 1.75 & 0.042 & 0.042 \\
1.5 & 0.168 & 0.283 & 1.68 & 0.053 & 0.049 \\
2.0 & 0.171 & 0.287 & 1.68 & 0.064 & 0.051 \\
3.0 & 0.179 & 0.308 & 1.72 & 0.075 & 0.055 \\
4.0 & 0.200 & 0.324 & 1.62 & 0.080 & 0.064 \\
5.0 & 0.201 & 0.323 & 1.61 & 0.088 & 0.073 \\
7.0 & 0.193 & 0.337 & 1.75 & 0.101 & 0.071 \\
10.0 & 0.230 & 0.351 & 1.53 & 0.104 & 0.076 \\
\hline
\end{tabular}

Table 9: Descriptive Tax Statistics: Unmarried Households, Two Children

\begin{tabular}{|l|c|c|c|c|c|}
\hline $\begin{array}{l}\text { Multiples of } \\
\text { Mean Income }\end{array}$ & $\begin{array}{c}\text { Avg. Tax Rate } \\
\text { (Mean) }\end{array}$ & $\begin{array}{c}\text { Marg. Tax Rate } \\
\text { (Mean) }\end{array}$ & Marg./Avg. & $\begin{array}{c}\text { Avg. Tax Rate } \\
\text { (St. Deviation) }\end{array}$ & $\begin{array}{c}\text { Marg. Tax Rate } \\
\text { (St. Deviation) }\end{array}$ \\
\hline 0.10 & 0.000 & 0.000 & - & 0.000 & 0.000 \\
0.25 & 0.000 & 0.082 & - & 0.004 & 0.075 \\
0.50 & 0.016 & 0.148 & 9.25 & 0.022 & 0.018 \\
0.75 & 0.062 & 0.151 & 2.44 & 0.023 & 0.021 \\
1.0 & 0.091 & 0.237 & 2.60 & 0.031 & 0.062 \\
1.5 & 0.133 & 0.275 & 2.07 & 0.035 & 0.025 \\
2.0 & 0.144 & 0.281 & 1.95 & 0.057 & 0.034 \\
3.0 & 0.181 & 0.301 & 1.66 & 0.067 & 0.058 \\
4.0 & 0.221 & 0.329 & 1.49 & 0.046 & 0.055 \\
5.0 & 0.236 & 0.348 & 1.47 & 0.058 & 0.052 \\
7.0 & 0.233 & 0.342 & 1.47 & 0.069 & 0.075 \\
10.0 & 0.253 & 0.353 & 1.40 & 0.085 & 0.081 \\
\hline
\end{tabular}


Table 10: Descriptive Tax Statistics: Unmarried Households, Two + Children

\begin{tabular}{|l|c|c|c|c|c|}
\hline $\begin{array}{l}\text { Multiples of } \\
\text { Mean Income }\end{array}$ & $\begin{array}{c}\text { Avg. Tax Rate } \\
\text { (Mean) }\end{array}$ & $\begin{array}{c}\text { Marg. Tax Rate } \\
\text { (Mean) }\end{array}$ & Marg./Avg. & $\begin{array}{c}\text { Avg. Tax Rate } \\
\text { (St. Deviation) }\end{array}$ & $\begin{array}{c}\text { Marg. Tax Rate } \\
\text { (St. Deviation) }\end{array}$ \\
\hline 0.1 & 0.000 & 0.000 & - & 0.000 & 0.000 \\
0.2 & 0.000 & 0.040 & - & 0.000 & 0.066 \\
0.5 & 0.009 & 0.146 & 16.22 & 0.019 & 0.023 \\
0.75 & 0.040 & 0.151 & 3.78 & 0.025 & 0.015 \\
1.0 & 0.069 & 0.200 & 2.90 & 0.037 & 0.070 \\
1.5 & 0.106 & 0.267 & 2.52 & 0.040 & 0.038 \\
2.0 & 0.126 & 0.261 & 2.07 & 0.036 & 0.045 \\
3.0 & 0.167 & 0.307 & 1.84 & 0.045 & 0.021 \\
4.0 & 0.196 & 0.316 & 1.61 & 0.039 & 0.041 \\
5.0 & 0.207 & 0.351 & 1.70 & 0.102 & 0.052 \\
7.0 & 0.265 & 0.393 & 1.48 & 0.058 & 0.037 \\
10.0 & 0.288 & 0.385 & 1.34 & 0.063 & 0.045 \\
\hline
\end{tabular}

Table 11: Tax Rate Distribution

\begin{tabular}{|l|c|c|}
\hline Statistic & Married & Unmarried \\
\hline \% with zero taxes & $14.5 \%$ & $31.8 \%$ \\
Median Tax rate & $8.0 \%$ & $5.6 \%$ \\
Mean Tax rate & $8.8 \%$ & $6.4 \%$ \\
& & \\
Tax Rate Defining & & \\
Bottom 80\% & $13.5 \%$ & $10.3 \%$ \\
Bottom 90\% & $16.5 \%$ & $14.0 \%$ \\
Bottom 95\% & $19.5 \%$ & $17.0 \%$ \\
Bottom 99\% & $27.5 \%$ & $22.5 \%$ \\
\hline
\end{tabular}


Table 12: Distribution of Tax Liabilities

\begin{tabular}{|l|c|}
\hline $\begin{array}{l}\text { Percentile } \\
\text { of Income }\end{array}$ & $\begin{array}{c}\text { Share of Total } \\
\text { Taxes Paid }\end{array}$ \\
\hline Bottom 20\% & $0.7 \%$ \\
$20-40 \%$ & $2.5 \%$ \\
$40-60 \%$ & $6.3 \%$ \\
$60-80 \%$ & $13.2 \%$ \\
$80-90 \%$ & $12.8 \%$ \\
$90-95 \%$ & $10.9 \%$ \\
$95-99 \%$ & $18.9 \%$ \\
$99-99.5 \%$ & $6.1 \%$ \\
$99.5-100 \%$ & $28.6 \%$ \\
& \\
Top 20\% & $77.3 \%$ \\
Top 10\% & $64.5 \%$ \\
Top 5\% & $53.7 \%$ \\
Top 1\% & $34.8 \%$ \\
\hline
\end{tabular}

Table 13: Before and After-Tax Income Distribution Statistics

\begin{tabular}{|l|c|c|}
\hline Percentile & $\begin{array}{c}\text { Before Tax } \\
\text { Share of } \\
\text { Total Income }\end{array}$ & $\begin{array}{c}\text { After Tax } \\
\text { Share of } \\
\text { Total Income }\end{array}$ \\
\hline Bottom 20\% & $3.4 \%$ & $3.8 \%$ \\
$20-40 \%$ & $6.9 \%$ & $7.7 \%$ \\
$40-60 \%$ & $11.6 \%$ & $12.5 \%$ \\
$60-80 \%$ & $18.8 \%$ & $19.7 \%$ \\
$80-90 \%$ & $14.3 \%$ & $14.5 \%$ \\
$90-95 \%$ & $10.2 \%$ & $10.1 \%$ \\
$95-99 \%$ & $14.5 \%$ & $13.8 \%$ \\
$99-99.5 \%$ & $4.0 \%$ & $3.7 \%$ \\
$99.5-100 \%$ & $16.2 \%$ & $14.3 \%$ \\
\hline Other Statistics & & \\
Gini Coefficient & 0.554 & 0.522 \\
Var-log Income & 0.85 & 0.76 \\
\hline
\end{tabular}


Table 14: Parametric Estimates: Log-specification, All and Married Households

\begin{tabular}{|c|c|c|c|c|c|c|}
\hline Estimates & All & $\begin{array}{c}\text { Married } \\
(\text { all })\end{array}$ & $\begin{array}{c}\text { Married } \\
\text { No Children }\end{array}$ & $\begin{array}{c}\text { Married } \\
\text { One Child }\end{array}$ & $\begin{array}{c}\text { Married } \\
\text { Two Children }\end{array}$ & $\begin{array}{c}\text { Married } \\
\text { Two + Children }\end{array}$ \\
\hline$\beta$ & 0.0400 & 0.0638 & 0.0582 & 0.0704 & 0.0789 & 0.0838 \\
$\alpha$ & 0.1127 & 0.0924 & 0.1028 & 0.0942 & 0.0763 & 0.0577 \\
St. Errors & & & & & & \\
$\beta$ & 0.0001 & 0.0002 & 0.0002 & 0.0004 & 0.0003 & 0.0005 \\
$\alpha$ & 0.0001 & 0.0001 & 0.0002 & 0.0003 & 0.0003 & 0.0003 \\
\hline
\end{tabular}

Table 15: Parametric Estimates: Log-specification, Unmarried Households

\begin{tabular}{|c|c|c|c|c|c|}
\hline Estimates & All & No Children & One Child & Two Children & Two + Children \\
\hline$\beta$ & 0.0451 & 0.0481 & 0.0726 & 0.0819 & 0.0787 \\
$\alpha$ & 0.1298 & 0.1392 & 0.1071 & 0.09 & 0.0721 \\
\cline { 5 - 6 } St. Errors & & & & & \\
$\beta$ & 0.0003 & 0.0003 & 0.0012 & 0.002 & 0.0042 \\
$\alpha$ & 0.0003 & 0.0003 & 0.0007 & 0.0011 & 0.002 \\
\hline
\end{tabular}

Table 16: Parametric Estimates: GS specification, All and Married Households

\begin{tabular}{|c|c|c|c|c|c|c|}
\hline Estimates & All & $\begin{array}{c}\text { Married } \\
(\text { all })\end{array}$ & $\begin{array}{c}\text { Married } \\
\text { No Children }\end{array}$ & $\begin{array}{c}\text { Married } \\
\text { One Child }\end{array}$ & $\begin{array}{c}\text { Married } \\
\text { Two Children }\end{array}$ & $\begin{array}{c}\text { Married } \\
\text { Two + Children }\end{array}$ \\
\hline$b$ & 0.2627 & 0.2471 & 0.2338 & 0.2746 & 0.2848 & 0.2897 \\
$s$ & 0.0123 & 0.0006 & 0.0032 & 0.0029 & 0.0007 & 0.0001 \\
$p$ & 0.9723 & 1.85 & 1.493 & 1.364 & 1.687 & 2.085 \\
St. Errors & & & & & & \\
\multicolumn{1}{c}{$b$} & 0.0015 & 0.0008 & 0.0011 & 0.0023 & 0.0017 & 0.002 \\
$s$ & 0.0001 & 0.00003 & 0.0002 & 0.0002 & 0.00005 & 0.00001 \\
$p$ & 0.006 & 0.0143 & 0.0189 & 0.0217 & 0.021 & 0.034 \\
\hline
\end{tabular}

Table 17: Parametric Estimates: GS specification, Unmarried Households

\begin{tabular}{|c|c|c|c|c|c|}
\hline Estimates & All & No Children & One Child & Two Children & Two + Children \\
\hline$b$ & 0.2346 & 0.2462 & 0.2254 & 0.2524 & 0.286 \\
$s$ & 0.0074 & 0.0311 & 0.0012 & 0.0002 & 0.0003 \\
$p$ & 1.415 & 0.8969 & 1.872 & 2.271 & 1.866 \\
& & & & & \\
St. Errors & & & & & 0.0275 \\
$b$ & 0.0022 & 0.0027 & 0.0064 & 0.01 & 0.0002 \\
$s$ & 0.0003 & 0.0005 & 0.0003 & 0.00008 & 0.23 \\
\hline
\end{tabular}


Table 18: Marginal Tax Rates: Statutory Rates, Log and GS Specifications

\begin{tabular}{|l|c|c|c|}
\hline $\begin{array}{l}\text { Multiples of } \\
\text { Mean Income }\end{array}$ & $\begin{array}{c}\text { Marginal Tax Rate } \\
\text { Statutory }\end{array}$ & $\begin{array}{c}\text { Marginal Tax Rate } \\
\text { Log Specification }\end{array}$ & $\begin{array}{c}\text { Marginal Tax Rate } \\
\text { GS Specification }\end{array}$ \\
\hline 0.10 & (Mean) & (Mean) & (Mean) \\
0.25 & 0.001 & 0.009 & 0.006 \\
0.50 & 0.073 & 0.068 & 0.029 \\
0.75 & 0.132 & 0.112 & 0.084 \\
1.0 & 0.147 & 0.138 & 0.133 \\
1.5 & 0.189 & 0.156 & 0.169 \\
2.0 & 0.264 & 0.182 & 0.209 \\
3.0 & 0.277 & 0.200 & 0.226 \\
4.0 & 0.297 & 0.226 & 0.239 \\
5.0 & 0.326 & 0.245 & 0.243 \\
7.0 & 0.340 & 0.259 & 0.245 \\
10.0 & 0.355 & 0.280 & 0.246 \\
\hline
\end{tabular}


Figure 1: Cumulative Distribution of Tax Rates

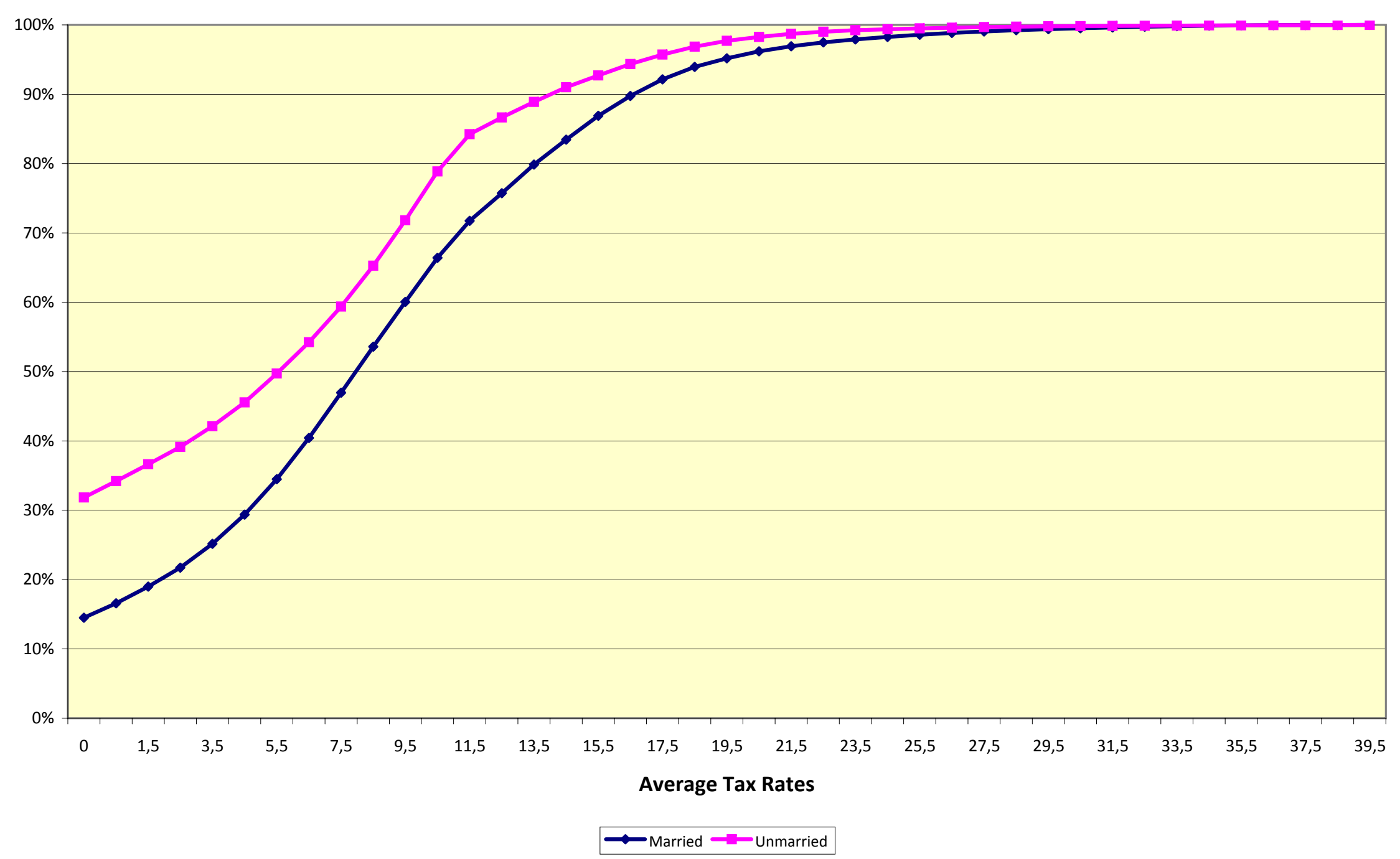


Figure 2: Average Tax Rates, Married Households

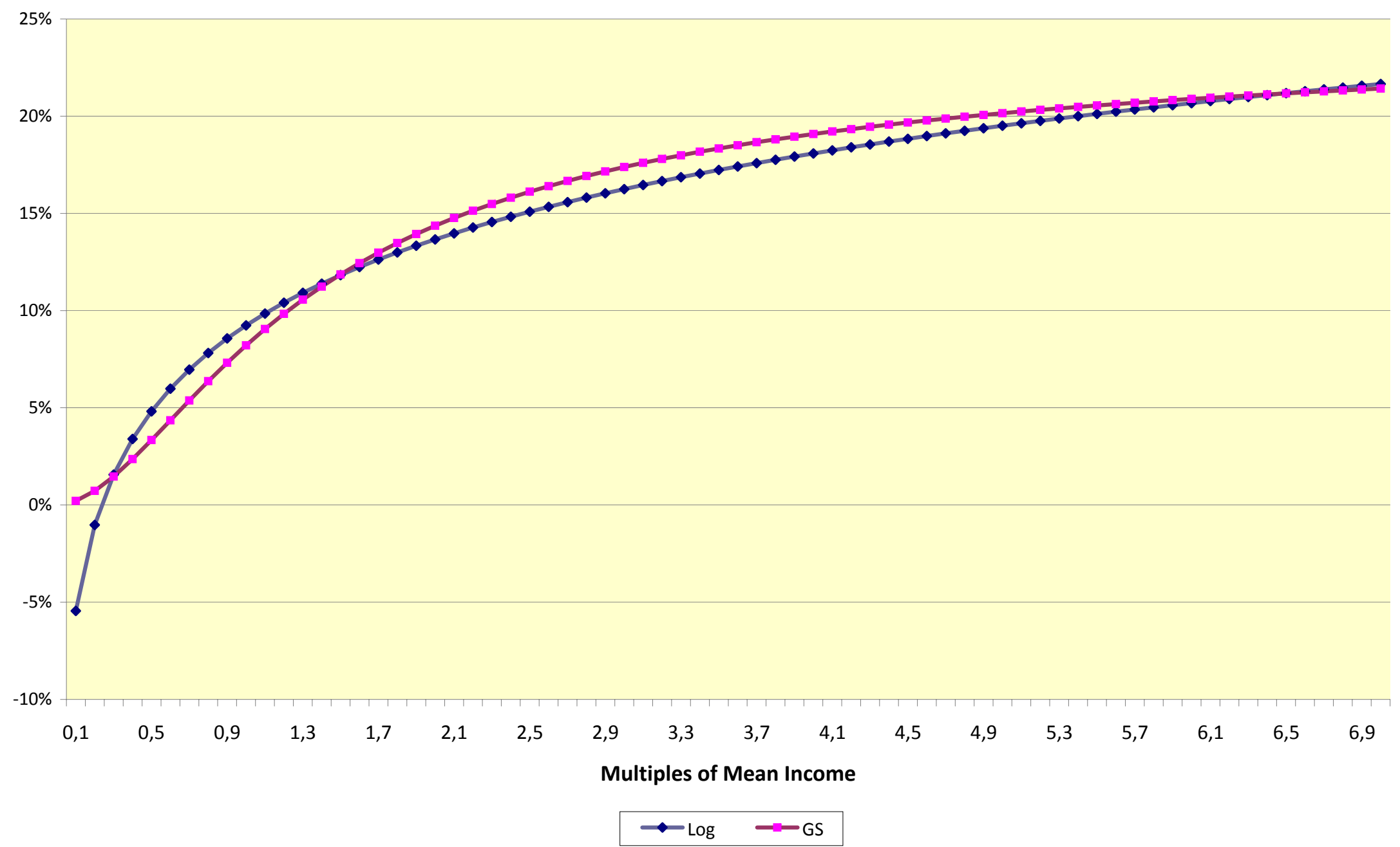


Figure 3: Marginal Tax Rates, Married Households

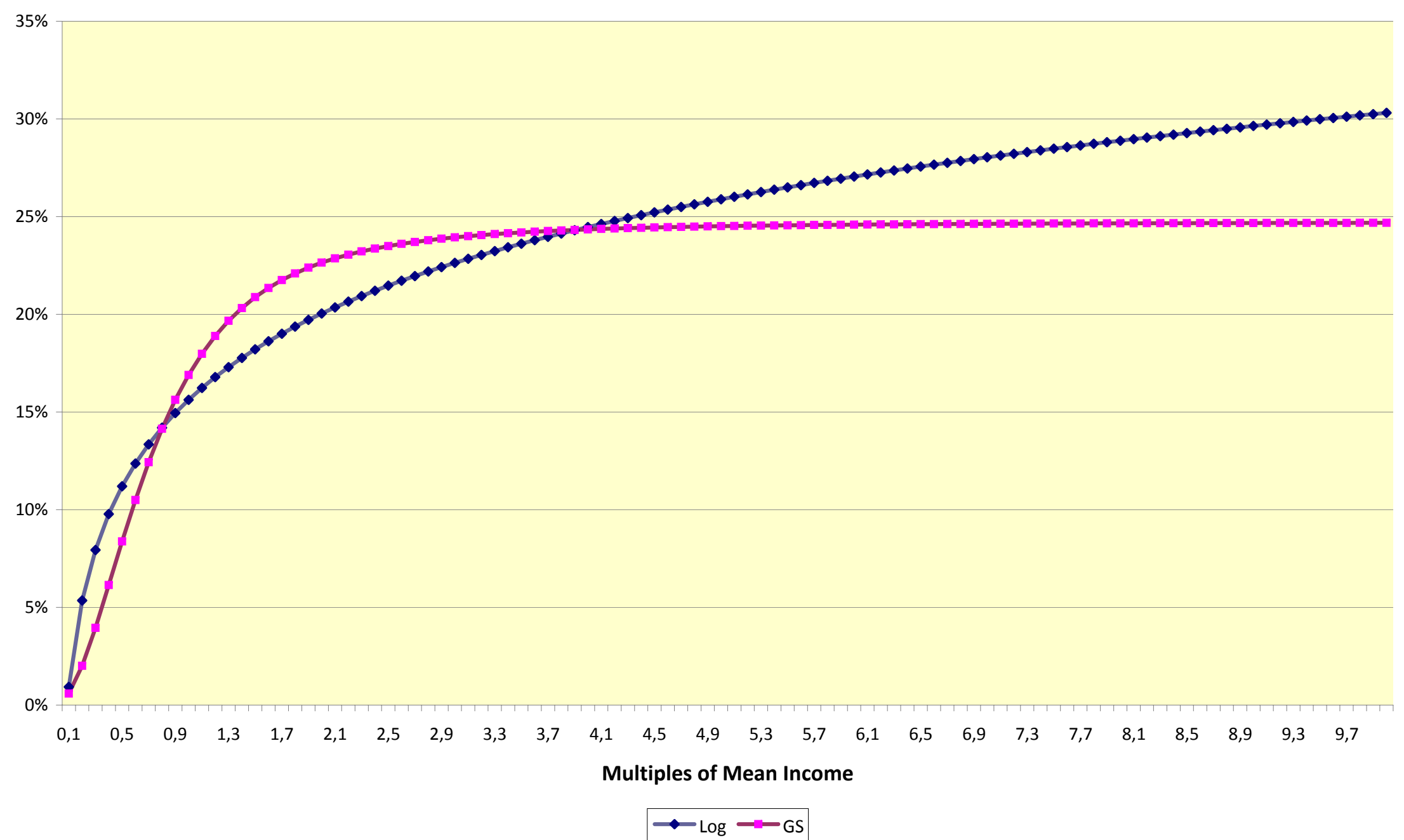


Figure 4: GS Average Tax Rates, All Households

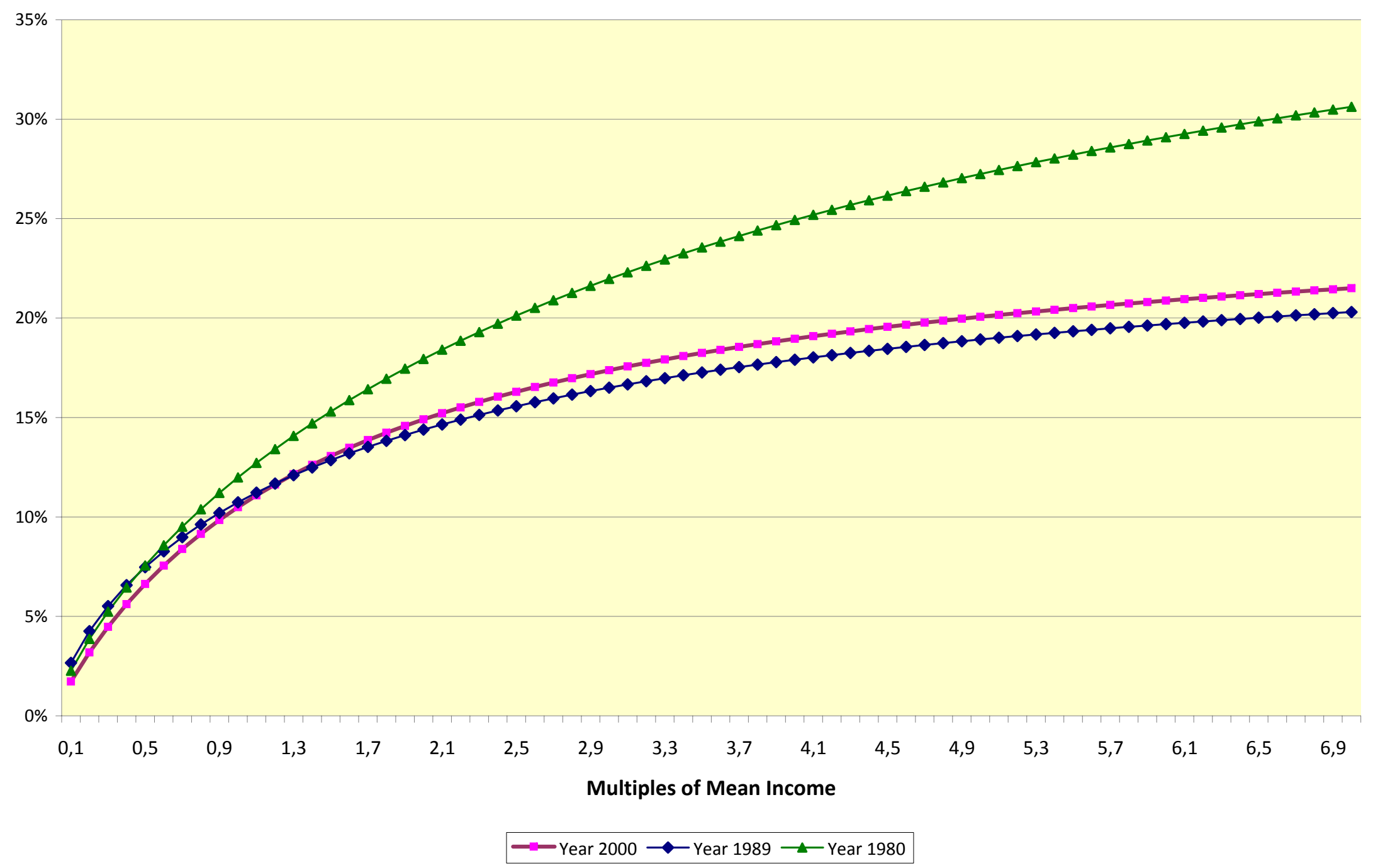

